\title{
EFEKTIVITAS PERASAN DAUN JERUK PURUT TERHADAP ANGKA KUMAN PADA PERALATAN MAKAN TAHUN 2017
}

Annisa Nur Islamiar, Narwati, Umi Rahayu

\begin{abstract}
ABSTRAK
Makanan adalah kebutuhan pokok untuk hidup manusia. Makanan dapat ditemui di restoran ataupun di pedagang kaki lima di tepi jalan yang mempunyai risiko penyakit yang ditransmisikan oleh bakteri patogen ketika tidak diolah dengan higienis. Alat makan merupakan salah satu risiko yang dapat menjadi sarana pertumbuhan dan perkembangbiakan mikroorganisme jika tidak dicuci dengan baik. Hal ini disebut dengan food-borne disease. Cara yang dapat digunakan untuk menekana terjadinya food-borne disease adalah dengan melakukan desinfeksi. Salah satu desinfektan yang dapat digunakan adalah daun jeruk purut yang dapat menurunkan angka kuman. Tujuan penelitian ini adalah menganalisis efektivitas daun jeruk purut terhadap angka kuman pada peralatan makan.

Metode penelitian ini adalah eksperimental menggunakan rancangan non equivalent control group. Data dianalisis menggunakan uji annova dengan tes LSD (Least Significant Difference).

Berdasarkan hasil penelitian didapatkan hasil yang signifikan bahwa daun jeruk purut dapat menurunkan angka kuman dan terjadi perbedaan yang signifikan pada kelompok kontrol. Kelompok yang dapat menurunkan nilai angka kuman tertinggi adalah dengan konsentrasi $100 \mathrm{mg} / 100 \mathrm{ml}$.

Kesimpulan yang dapat ditarik dari penelitian ini adalah variasi konsentrasi daun jeruk purut dapat menentukan nilai penurunan angka kuman. Dalam penelitian ini, konsentrasi daun jeruk purut yang efektif untuk menirunkan angka kuman 100 mg / 100 $\mathrm{ml}$.
\end{abstract}

Keywords: daun jeruk purut, perelatan makan, angka kuman

\section{PENDAHULUAN}

Makanan merupakan kebutuhan dasar bagi kelangsungan hidup manusia, sehingga setiap orang perlu dijamin dalam memperoleh pangan yang bermutu dan aman. Bahan pangan yang tidak diproduksi dengan cara yang baik dan benar dapat menjadi sumber mikroorganisme dan kontaminan kimia yang dapat berbahaya dan menyebabkan penyakit kepada manusia. Terjadinya kasus-kasus keracunan makanan seharusnya tidak perlu terjadi apabila produk pangan diolah dengan prosedur pengolahan yang benar (Badan POM,2007).

Makanan yang berada di rumah makan, restoran atau di pinggiran jalan akan menjadi media tempat penularan penyakit patogen apabila tidak diolah dan ditangani dengan baik karena dalam penanganan makanan dapat memasukkan dan menyebarkan mikroorganisme patogen. Penularan penyakit tersebut dapat terjadi secara langsung maupun tidak langsung (Purnawijayanti, 2001).

Keberhasilan suatu proses pencucian dapat dilihat dengan semakin rendahnya jumlah mikroba dalam alat makan tersebut yang dapat diketahui dengan uji angka kuman. Di Indonesia telah dibuat peraturan dalam bentuk Permenkes RI No. 1096/Menkes/SK/V/2011 yang mengatakan bahwa untuk persyaratan peralatan makan jumlah koloni $/ \mathrm{cm}^{2}$ permukaan alat harus nol dan tidak mengandung E. coli (DepkesRI, 2011). Peralatan makan dapat menjadi media penularan penyakit bila tidak dibersihkan dengan baik. Upaya pencegahan penularan penyakit melalui alat makan biasanya menggunakan deterjen atau sanitiser. Cara ini dapat menghasilkan limbah air yang dapat menimbulkan pencemaran lingkungan. Upaya desinfeksi terhadap peralatan makan dapat menggunakan desinfektan kimia maupun desinfektan alami. Salah satu desinfektan 
alami yang dapat digunakan adalah daun jeruk purut, karena daun jeruk purut dapat mengurangi angka kuman dan mengurangi pencemaran lingkungan (Sulistyani, 2004).

Pada jurnal penelitian Sulistiyani, Ulfa Nurullita, dan Dina Nuryani volume 1 nomor 2 tahun 2004, yang berjudul Perbedaan Jumlah Mikroba pada Alat Makan Sebelum dan Sesudah dicuci dengan Jeruk Purut (Citrus histrix. DC), didapatkan hasil bahwa perasan daun jeruk purut dapat menurunkan angka kuman, tetapi dengan konsentrasi 50 $\mathrm{mg} / 100 \mathrm{ml}$ masih mendapatkan hasil jauh di atas nilai ambang batas yang ditentukan Peraturan Menteri Kesehatan Republik Indonesia, yaitu 0 koloni $/ \mathrm{cm}^{2}$. Tujuan penelitian ini adalah menganalisis efektivitas perasan daun jeruk purut terhadap angka kuman pada peralatan makan.

\section{METODE PENELITIAN}

Rancangan penelitian ini bersifat eksperimen semu (quasi experiment), memakai kelompok kontrol dengan menggunakan rancangan non equivalent control group (Notoatmodjo, 2012). Dengan replikasi sebanyak 9 kali. Masingmasing perlakuan menggunakan 4 piring, jadi total seluruh piring sebanyak 144 buah. Sampel yang dipakai adalah piring yang ada di warung Bu Siswo. Waktu penelitian dilaksanakan pada bulan Mei 2017. Variabel terikat pada penelitian ini adalah angka kuman pada piring. variabel bebasnya adalah Konsentrasi perasan daun jeruk purut $50 \mathrm{mg} / 100 \mathrm{ml}, 75$ $\mathrm{mg} / 100 \mathrm{ml}$, dan $100 \mathrm{mg} / 100 \mathrm{ml}$.

Pada penelitian ini menggunakan analisis data jenis one way Anova dan dilanjutkan uji LSD (Least Significant Difference).

\section{HASIL DAN PEMBAHASAN}

Pemeriksaan Angka Kuman Sebelum Menggunakan Perasan Daun Jeruk Purut Tabel 1

Nilai Angka Kuman Pada Alat Makan Sebelum Menggunakan Perasan Daun Jeruk Purut

\begin{tabular}{cccc} 
No. & Replikasi & $\begin{array}{c}\text { Angka } \\
\text { Kuman } \\
(\text { koloni/cm }\end{array}$ & NAB \\
\hline 1. & I & 21,83 & 0 \\
\hline 2. & II & 24,33 & 0 \\
\hline 3. & III & 20,35 & 0 \\
\hline 4. & IV & 22,16 & 0 \\
\hline 5. & V & 22,82 & 0 \\
\hline 6. & VI & 21,54 & 0 \\
\hline 7. & VII & 23,25 & 0 \\
\hline 8. & VIII & 22,08 & 0 \\
\hline 9. & IX & 22,44 & 0 \\
\hline & Rata-rata & $\mathbf{2 2 , 3 1}$ \\
\hline
\end{tabular}

Berdasarkan tabel di atas hasil pemeriksaan angka kuman pada piring sebelum dicuci dengan perasan daun jeruk purut didapatkan hasil rata-rata $22,31 \mathrm{koloni} / \mathrm{cm}^{2}$, dengan nilai minimum angka kuman $20,35 \mathrm{koloni} / \mathrm{cm}^{2}$ dan maksimum 24,33 koloni/ $\mathrm{cm}^{2}$. Hasil pemeriksaan angka kuman tersebut di atas 0 koloni $/ \mathrm{cm}^{2}$, sehingga tidak memenuhi persyaratan berdasarkan Keputusan Menteri Kesehatan Republik Indonesia No 1096/Menkes/SK/VII/2011 yang menjelaskan bahwa peralatan yang kontak langsung dengan makanan yang siap disajikan tidak boleh mengandung angka kuman melebihi ambang batas (tidak boleh lebih dari 0 koloni $/ \mathrm{cm}^{2}$.

Tingginya angka kuman pada peralatan makan salah satu faktornya dari proses pencucian peralatan makan yang tidak benar. Sejalan dengan penelitian Dewi, dkk (2003) didapatkan hasil bahwa pencucian peralatan makan yang tidak benar dapat mengakibatkan tingginya angka kuman pada peralatan makan. Pencucian peralatan makan yang tidak benar adalah dengan air tidak mengalir dan air tidak selalu diganti (Haderiah, 
dkk, 2015). Pencucian peralatan makan yang benar harus menggunakan air banyak, mengalir, dan selalu diganti (DepKes RI, 2006). Ketidaktahuan pengelola makanan dalam upaya membersihkan peralatan makan dapat menjadi penyebab terjadinya gangguan kesehatan dan penyakit akibat bawaan makanan (DepKes RI, 2004).

Menurut DepKes RI (2006) teknik pencucian yang benar adalah dengan Scraping yaitu memisahkan sisa kotoran dan sisa-sisa makanan yang terdapat pada peralatan yang akan dicuci; Flusing yaitu mengguyur air ke dalam peralatan yang akan dicuci sehingga terendam seluruh permukaan peralatan. Sebelum peralatan yang akan dicuci telah dibersihkan dari sisa makan; Washing yaitu mencuci peralatan dengan cara menggosok dan melarutkan sisa makanan dengan zat pencuci atau detergen; Rinsing yaitu mencuci peralatan yang telah digosok detergen sampai bersih dengan cara dibilas dengan air bersih. Pada tahap ini penggunaan air harus banyak, mengalir, dan selalu diganti. Setiap peralatan yang dibersihkan dibilas dengan cara menggosok-gosok dengan tangan sampai terasa kesat, tidak licin; Sanitizing/Desinfection yaitu tidak untuk membebashamakan peralatan setelah proses pencucian; Towelling (mengeringkan), yaitu mengusap kain lap bersih atau mengeringkan dengan menggunakan kain atau handuk dengan maksud untuk menghilangkan sisa-sisa kotoran yang mungkin masih menempel sebagai akibat proses pencucian seperti noda detergen, noda klor, dan sebagainya.

\section{Pemeriksaan Angka Kuman Setelah Menggunakan Variasi Konsentrasi Perasan Daun Jeruk Purut}

Tabel 2

Nilai Angka Kuman Pada Alat Makan Setelah Menggunakan Perasan Daun Jeruk Purut

\begin{tabular}{|c|c|c|c|c|}
\hline \multirow[b]{2}{*}{ No } & \multirow[b]{2}{*}{ Replikasi } & \multicolumn{3}{|c|}{ Angka Kuman (koloni $/ \mathrm{cm}^{2}$ ) } \\
\hline & & $\begin{array}{c}\text { Konsentrasi } 50 \\
\mathrm{mg} / \\
100 \mathrm{ml} \\
\end{array}$ & $\begin{array}{c}\text { Konsentrasi } 75 \\
\mathrm{mg} / \\
100 \mathrm{ml} \\
\end{array}$ & $\begin{array}{c}\text { Konsentrasi } 100 \\
\mathrm{mg} / \\
100 \mathrm{ml}\end{array}$ \\
\hline 1 & I & 14,23 & 10,36 & 4,28 \\
\hline 2 & II & 13,96 & 9,88 & 4,56 \\
\hline 3. & III & 14,06 & 10,12 & 5,14 \\
\hline 4. & IV & 14,24 & 11,06 & 4,67 \\
\hline 5. & $\mathrm{~V}$ & 15,02 & 9,06 & 4,82 \\
\hline 6. & VI & 13,86 & 9,28 & 5,08 \\
\hline 7. & VII & 14,36 & 10,24 & 4,94 \\
\hline 8. & VIII & 13,84 & 9,92 & 5,26 \\
\hline 9. & IX & 14,16 & 9,64 & 4,28 \\
\hline & $\begin{array}{l}\text { Rata- } \\
\text { rata }\end{array}$ & 14,19 & 9,95 & 4,78 \\
\hline
\end{tabular}

Berdasarkan tabel di atas dapat dilihat bahwa rata-rata angka kuman pada variasi konsentrasi $50 \mathrm{mg} / 100 \mathrm{ml}$ menunjukkan jumlah angka kuman pada piring paling tinggi $\left(14,19 \mathrm{koloni} / \mathrm{cm}^{2}\right)$ dan variasi konsentrasi $100 \mathrm{mg} / 100 \mathrm{ml}$ menunjukkan jumlah angka kuman pada piring paling rendah $\left(4,78\right.$ koloni/ $\left.\mathrm{cm}^{2}\right)$. Data tersebut menunjukkan bahwa ratarata angka kuman pada piring sesudah dicuci dengan perasan daun jeruk purut menunjukkan penurunan jumlah angka kuman setiap peningkatan konsentrasi perasan daun jeruk purut atau dengan kata lain semakin besar konsentrasi perasan daun jeruk purut semakin menurun jumlah angka kuman pada piring. Hal ini karena semakain besar konsentrasi perasan daun jeruk purut untuk mencuci piring kemungkinan piring mendapatkan saponin yang terkandung dalam daun jeruk purut semakin besar. Karena saponin adalah kandungan yang paling besar dalam daun jeruk purut. 
Perbedaan Angka Kuman pada Piring Sebelum dan Sesudah diberi Variasi Konsentrasi Perasan Daun Jeruk Purut

\begin{tabular}{|c|c|c|c|}
\hline \multirow[b]{2}{*}{ Rep } & \multicolumn{3}{|c|}{ Perbedaan Angka Kuman (koloni/ $\mathrm{cm}^{2}$ ) } \\
\hline & $\begin{array}{l}\text { Konsentrasi } \\
50 \mathrm{mg} / 100 \mathrm{ml}\end{array}$ & $\begin{array}{c}\text { Konsentrasi } \\
75 \mathrm{mg} / 100 \mathrm{ml}\end{array}$ & $\begin{array}{c}\text { Konsentrasi } \\
100 \mathrm{mg} / \\
100 \mathrm{ml}\end{array}$ \\
\hline I & 7,6 & 11,47 & 17,55 \\
\hline II & 10.37 & 14,45 & 19,77 \\
\hline III & 6,29 & 10,23 & 15,21 \\
\hline IV & 7,92 & 11,1 & 17,49 \\
\hline V & 7,8 & 13,76 & 18 \\
\hline VI & 7,68 & 12,26 & 16,46 \\
\hline VII & 8,89 & 13,01 & 18,31 \\
\hline VIII & 8,24 & 12,16 & 16,82 \\
\hline IX & 8,28 & 12,8 & 18,16 \\
\hline Rata-rata & 8,12 & 12,36 & 17,53 \\
\hline
\end{tabular}

Perbedaan angka kuman pada piring sebelum dan sedudah dicuci dengan variasi konsentrasi perasan daun jeruk purut secara statistik menunjukkan ada perbedaan yang signifikan dengan nilai $p$ value 0,00 . Hal ini sesuai dengan analisa tabel yang menunjukkan rata-rata angka kuman pada setiap variasi konsentrasi berbeda.

Adanya perbedaan angka kuman pada piring sebelum dan sesudah dicuci dengan perasan daun jeruk purut karena daun jeruk purut mengandung senyawa polifenol $1,96 \%$, saponin $2,15 \%$, minyak atsiri $0,88 \%$, flavonoid 1,05 , tanin, kumarin $0,31 \%$, asam sitrat 2,03\%, steroid 0,24 , dan triterpenoid $0,41 \%$. Hal ini sejalan dengan penelitian Sulistiyani (2004) bahwa daun jeruk purut mengandung senyawa yang berfungsi sebagai desinfektan. Menurut penelitian Sulistiyani, dkk (2004) menjelaskan bahwa daun jeruk purut mengandung polifenol yang dapat digunakan sebagai desinfektan.

Saponin berperan sebagai antimikroba pada Stapylococcus aureus, senyawa saponin bekerja sebagai antimikroba dengan cara merusak membran sitoplasma dan membunuh sel (Soetan et al, 2006).

Minyak atsiri dapat menghambat beberapa jenis bakteri merugikan seperti Escherichia coli, Salmonella $s p$, Staphylococcus aureus, Klebsiella, dan Pasteurella (Agusta, 2000) yang sejalan dengan penelitian Ratna, dkk (2011) bahwa minyak atsiri daun jeruk purut mempunyai aktivitas antibakteri terhadap Staphylococcus aureus dan Escherichia coli.

Flavonoid dapat menyebabkan terjadinya kerusakan permeabilitas dinding sel bakteri (Ardo, 2005). Tanin bekerja dengan cara menghambat pertumbuhan bakteri dengan melakukan denaturasi protein dan menurunkan tegangan permukaan, sehingga permeabilitas bakteri meningkat. Kerusakan dan peningkatan permeabilitas sel bakteri menyebabkan pertumbuhan sel menjadi terhambat dan akhirnya dapat menyebabkan kematian sel (Akiyanma et al, 2001). Menurut Cowan (1999) dalam penelitian Agung (2015) kumarin merupakan senyawa fenolik yang menghambat pertumbuhan mikroba dengan menginaktivasi enzim dan merusak dinding sel.

Asam sitrat bersifat merusak atau mengganggu kestabilan zat pelindung dari dinding sel (Blaszyk et al, 1998).

Menurut Menurut Putra (2007) dalam penelitian Dwi Budi Wiyanto (2010) mekanisme kerja steroid dalam menghambat mikroba adalah dengan merusak membran plasma sel mikroba, sehingga menyebabkan bocornya sitoplasma keluar sel yang selanjutnya menyebabkan kematian sel.

Triterpenoid dapat menghambat pertumbuhan bakteri Staphylococcus aureus dan Escherichia coli (Wiwik, 2010). 


\section{Analisis Efektivitas Perasan Daun Jeruk Purut terhadap Angka Kuman pada Piring yang dicuci}

Berdasarkan uji statistik Anova diperoleh hasil $P=0,000<a(0,05)$ yang berarti ada pengaruh yang signifikan antara perasan daun jeruk purut terhadap angka kuman pada piring.

Konsentrasi perasan daun jeruk purut dalam menurunkan angka kuman pada piring paling kecil terdapat pada konsentrasi $50 \mathrm{mg} / 100 \mathrm{ml}$ dan paling besar terdapat pada konsentrasi 100 $\mathrm{mg} / 100 \mathrm{ml}$. Hasil analisis tabel menunjukkan secara umum terjadi peningkatan rata-rata jumlah angka kuman setiap peningkatan konsentrasi. $\mathrm{Hal}$ ini sejalan dengan penelitian Miftahendarwati (2014) bahwa semakin meningkatnya konsentrasi ekstrak daun jeruk purut, maka lebih mampu menghambat bakteri Strptococcus mutans.

Angka kuman pada hasil penelitian ini jika dibandingkan dengan Kepmenkes no. 1096 tahun 2011 masih di bawah nilai ambang batas.

\section{Kesimpulan}

Berdasarkan hasil penelitian tentang efektivitas perasan daun jeruk purut terhadap angka kuman pada peralatan makan dapat disimpulkan bahwa daun jeruk purut dengan variasi konsentrasi efektif menurunkan angka kuman, hal ini dapat dijelaskan sebagai berikut :

1. Hasil rata-rata pemeriksaan angka kuman pada piring sebelum dicuci adalah 22,31 koloni/ $\mathrm{cm}^{2}$

2. Hasil pemeriksaan angka kuman pada piring yang sudah dicuci dengan perasan daun jeruk purut konsentrasi $50 \mathrm{mg} / 100 \mathrm{ml}$ memiliki rata-rata 14,19 koloni/ $\mathrm{cm}^{2} ; 75 \mathrm{mg} / 100 \mathrm{ml}$ memiliki rata-rata $9,95 \mathrm{koloni} / \mathrm{cm}^{2}$; dan 100 $\mathrm{mg} / 100 \mathrm{ml}$ memiliki rata-rata 4,78 koloni $/ \mathrm{cm}^{2}$.

3. Hasil angka kuman pada piring sesudah dicuci dengan perasan daun jeruk purut konsentrasi $50 \mathrm{mg} / 100 \mathrm{ml}$, konsentrasi $75 \mathrm{mg} / 100 \mathrm{ml}$, dan konsentrasi $100 \mathrm{mg} / 100 \mathrm{ml}$ mengalami penurunan pada semua perlakuan. Perbedaan penurunan angka kuman antara sebelum dan sesudah dicuci dengan perasan daun jeruk purut konsentrasi $50 \mathrm{mg} / 100 \mathrm{ml}$ memiliki rata-rata penurunan sebesar 8,12 koloni/ $\mathrm{cm}^{2}$; konsentrasi $75 \mathrm{mg} / 100 \mathrm{ml}$ memiliki rata-rata penurunan sebesar $12,36 \mathrm{koloni} / \mathrm{cm}^{2}$; dan konsentrasi 100 $\mathrm{mg} / 100 \mathrm{ml}$ memiliki rata-rata penurunan sebesar $17,53 \mathrm{koloni} / \mathrm{cm}^{2}$.

4. Perasan daun jeruk purut konsentrasi $100 \mathrm{mg} / 100 \mathrm{ml}$ paling efektif untuk menurunkan angka kuman pada piring dibanding $50 \mathrm{mg} / 100 \mathrm{ml}$ dan 75 $\mathrm{mg} / 100 \mathrm{ml}$.

\section{Saran}

1. Bagi Masyarakat

Perasan daun jeruk purut dapat digunakan sebagai alternatif oleh pedagang makanan (warung makanan) sebagai bahan alami untuk mencuci piring (mengurangi jumlah angka kuman pada alat makan).

2. Bagi Peneliti Lain

Perlu diteliti lebih lanjut tingkat konsentrasi perasan daun jeruk purut yang efektif untuk menurunkan jumlah angka kuman sesuai dengan Kemenkes 1096 tahun 2011.

\section{DAFTAR PUSTAKA}

Agusta, A, 2000, Minyak Atsiri Tumbuhan Tropika Indonesia. Bandung: Penerbit Institusi Teknologi Bandung.

Akiyanma et al, 2001, Antibacterial action of several tannin agains Staphylococcus aureus. 48 : 487-491 diakses 8 Juli 2017, $<$ https://www.ncbi.nlm.nih.gov/pub med/11581226>

Blaszyk M, Holley RA. 1998. Interaction of monolaurin, eugenol and sodium citrace on growth of common meat spoilage and pathogenic organisms. 39; 175-183 diakses 12 Juli, $<$ http://www.sciencedirect.com/scie nce/article/pii/S0168160597001347>

DepKes RI, 2004. Tentang Bakteri Pencemar Makanan dan Penyakit Bawaan Makanan, Modul 4, Jakarta

DepKes RI, 2011. Peraturan Menteri Kesehatan RI No. 
1096/Menkes/Per/VI/2011 tentang Higiene Sanitasi Jasaboga, Jakarta.

Haderiah, dkk, 2015, Studi Kualitas Bakteriologis Peralatan Makan pada Rumah Makan di Kota Makassar, vol. 1, no. 2, diakses 12 Juli 2017.

$<$ journal.uin-

alauddin.ac.id/index.php/higiene/arti cle/download/1243/1228>

Indonesian Public Health, 2016. FaktorFaktor yang Mempengaruhi Angka Kuman pada Peralatan Makan. http://www.indonesianpublichealth.com/angka-kumanperalatan-makanan/. 6 Februari 2017

Miftahendarwati. 2014. Efek Antibakteri Ekstrak Daun Jeruk Purut (Citrus hystrix) terhadap Bakteri Streptococcus mutans (in vitro. Makassar, Fakultas Kedokteran Gigi, Universitas Hasanuddin.

Notoatmodjo, Soekidjo. 2012. Metodologi Penelitian Kesehatan. Jakarta: Rineka Cipta

Purnawijayanti, H. 2001, Sanitasi, Higiene dan Keselamatan Kerja dalam Pengolahan Makanan. Yogyakarta: Kanisius. https://books.google.co.id/books?id= 6ktgJjJK5M4C\&printsec $=$ frontcover\& $\mathrm{hl}=\mathrm{id} \# \mathrm{v}=$ onepage\& $\mathrm{q} \& \mathrm{f}=$ false. Februari 2017

Sabir, Ardo, 2005, Aktivitas Antibakteri Flavonoid Propolis Trigona sp terhadap Bakteri Streptococcus mutans (in vitro), vol. 38, no. 3, diakses 8 Juli 2017, $<$ http://journal.unair.ac.id/in-vitroantibacterial-activity-of-flavonoidstrigona-sp-propolis-againststreptococcus-mutans-article-653media-2-category-3.html>

Soetan KO et al. 2006. Evaluation of the antimicrobial activity of saponins extract of Sorghum Bicolor L. Moench. African Journal of Biotechnology 5: 2405-2407 diakses 8 Juli 2017,
$<$ http://www.academicjournals.org/j ournal/AJB/articleabstract/A8C44408956>

Sulistiyani, dkk, 2004, Perbedaan Jumlah Mikroba pada Alat Makan sebelum dan sesudah dicuci dengan Daun Jeruk Purut, vol. 1, no. 2, diakses 30 Januari 2017, <jurnal.unimus.ac.id/index.php/jkmi/ article/download/376/421>

Suryani, Dyah, 2014, Keberadaan Angka Kuman Ikan Bawal Bakar dan Peralatan Makan Bakar, vol. 2, no. 2, hal.191-196, diakses 6 Juli 2017, $<$ https://media.neliti.com/media/pub lications/25421-ID-keberadaanangka-kuman-ikan-bawal-bakar-danperalatan-makan-bakar.pdf >

Susanna, Dewi, dkk 2003, Pemantauan Kualitas Makanan Ketoprak dan Gado-Gado di Lingkungan Kampus UI Depok, melalui Pemeriksaan Bakteriologis, vol. 7, no. 1, diakses 12 Juli 2017, https://www.researchgate.net/profile LDewi Susanna/publication/4740679 8 PEMANTAUAN KUALITAS MAKAN AN KETOPRAK DAN GADOGADO DI LINGKUNGAN KAMPUS U I DEPOK MELALUI PEMERIKSAAN BAKTERIOLOGIS/links/572180ad08a e5454b2310835/PEMANTAUANKUALITAS-MAKANAN-KETOPRAKDAN-GADO-GADO-DI-LINGKUNGANKAMPUS-UI-DEPOK-MELALUIPEMERIKSAAN-BAKTERIOLOGIS.pdf

Yuliana, Ratna, dkk, 2011, Aktivitas Antibakteri Minyak Atsiri Daun Jeruk Purut (Citrus Hystrix) terhadap Staphylococcus Aureus dan Escherichia coli, vol. 12, no. 2, diakses 1 Maret 2017, $<$ journals. ums.ac.id/index.php/phar macon/article/download/31/29> 